\title{
Bio-efficacy of insecticides against Conogethes punctiferalis on castor
}

\author{
R.D. PATEL* AND P. K. BORAD ${ }^{1}$
}

Main Cotton Research Station (N.A.U.), SURAT (GUJARAT) INDIA

${ }^{1}$ Department of Entomology, B.A. College of Agriculture, Ananad Agricultural University, ANAND (GUJARAT) INIDIA

\section{ARITCLE INFO}

Received : 27.02 .2016

Revised : 07.08 .2016

Accepted : 21.08.2016

KEY WORDS :

Bio-efficacy, Insecticides, Economics, Capsule borer, Castor, $\mathrm{C}: \mathrm{B}$ ratio

*Corresponding author:

Email : rdpatel.59119@yahoo.com

\begin{abstract}
Studies on bio-efficacy of insecticides against castor capsule borer, Conogethes (=Dichocrocis) punctiferalis Guenee on castor were carried out during Kharif, 201112. The results on efficacy of insecticides showed that chlorantraniliprole 20 SC @ 0.006 per cent and indoxacarb 14.5 SC @ 0.015 per cent were found superior and recorded 7.92 and 8.12 per cent capsule damage, respectively during spray schedule. At harvest, plots treated with chlorantraniliprole $20 \mathrm{SC}(0.006 \%)$, indoxacarb $14.5 \mathrm{SC}$ $(0.015 \%)$ and emamectin benzoate $5 \mathrm{WG}(0.002 \%)$ had found lower per cent capsules damage. Statistically higher castor seed yield was recorded in chlorantraniliprole @ $0.006 \%$ (3185 kg/ha), indoxacarb @ 0.015\% (3110 kg/ha) and emamectin benzoate @ $0.002 \%(2760 \mathrm{~kg} / \mathrm{ha})$. However, cost benefit ratio was highest in indoxacarb $14.5 \mathrm{SC}$ (1:16.62) followed by alphamethrin $10 \mathrm{EC}(1: 15.73)$ and chlorantraniliprole $20 \mathrm{SC}(1: 12.02)$.
\end{abstract}

How to view point the article : Patel, R.D. and Borad, P.K. (2016). Bio-efficacy of insecticides against Conogethes punctiferalis on castor. Internat. J. Plant Protec., 9(2) : 409-412, DOI : 10.15740/HAS/IJPP/9.2/409-412. 